Vasvári, Louise O. "Identity and Intergenerational Remembrance Through Traumatic Culinary Nostalgia: Three Generations of Hungarians of Jewish Origin." Hungarian Cultural Studies. e-Journal of the American Hungarian Educators Association, Volume 11 (2018) DOI: 10.5195/ahea.2018.322

\title{
Identity and Intergenerational Remembrance Through Traumatic Culinary Nostalgia: Three Generations of Hungarians of Jewish Origin
}

\section{Louise O. Vasvári}

Abstract: In my interdisciplinary analysis of foodways which combines Gender Studies with Holocaust Studies, I aim to demonstrate the cultural and gendered significance of the wartime sharing of recipes among starving women prisoners in concentration camps. This study will further discuss the continuing importance of food talk and food writing in the aftermath of the Holocaust, with an emphasis on the memory work of Hungarian survivors and their descendants. Fantasy cooking and recipe creation, or "cooking with the mouth," as it was called in many camps, was a way for many inmates to maintain their identities and connections to their ethnic and family history, a survival technique that may have influenced the depiction of food memories and their continuing role in the postwar memoir writing of survivor women. I will also examine the continued use of food talk as a genealogy of intergenerational remembrance and transmission in the post-memory writing of second-generation and even third-generation daughters and (very occasionally) sons of Hungarian origin. Studying multigenerational Holocaust alimentary writing has become particularly urgent today because we are approaching a biological and cultural caesura, at which juncture direct survivors will disappear and we will need new forms of transmission to reshape Holocaust memories for the future.

Keywords: Foodways, Holocaust, memory studies, postmemory, deep memory, culinary nostalgia

Biography: Louise O. Vasvári (M.A. and Ph.D., UC, Berkeley) is Professor Emerita of Comparative Literature and of Linguistics at Stony Brook University. She currently teaches in the Linguistics Department at NYU and is also Affiliated Professor at the University of Szeged. She works in medieval studies, diachronic and socio-linguistics, Holocaust studies, and Hungarian Studies, all informed by gender theory within a broader framework of comparative cultural studies. She has published with Steven Tötösy, Imre Kertész and Holocaust Literature (2005), Comparative Central European Holocaust Studies (2009), and Comparative Hungarian Cultural Studies (2011). louise.vasvari@stonybrook.edu

* This study was prepared in part with the support of a 2015-2016 Senior Core Fellowship from the Institute of Advanced Studies of the Central European University of Budapest.

(cc) $\mathrm{Br}$

ULIS D-Serle
New articles in this journal are licensed under a Creative Commons Attribution 4.0 International License.

This journal is published by the University Library System of the University of Pittsburgh as part of its D-Scribe Digital Publishing Program and is cosponsored by the University of Pittsburgh Press 
Vasvári, Louise O. "Identity and Intergenerational Remembrance Through Traumatic Culinary Nostalgia: Three Generations of Hungarians of Jewish Origin." Hungarian Cultural Studies. e-Journal of the American Hungarian Educators Association, Volume 11 (2018) DOI: 10.5195/ahea.2018.322

The present study is part of a larger project examining various forms of life writing created by several hundred women survivors of the Holocaust. While most of these works can be more traditionally classified as diaries or memoirs, the term life writing can be taken far more broadly, as I have discussed elsewhere (Vasvári 2016). In their new, revised edition of their Reading Autobiography, Sidonie Smith and Julia Watson (2010: 148-150) include new subcategories of what they call new kinds of memoirs, some of which were formerly considered marginal. Among these new genres Smith and Watson include gastrography, or "personalized recipe books," the term they use to designate any form of life writing in which the story of the self is closely linked to the production, preparation and/or consumption of food. A variety of alternate names have been proposed for this genre by Carol Bardenstein (357), such as cookbook memoirs, memoirs with recipes, culinary memoirs, collective memory cookbooks, nostalgia cookbooks, etc. While these subcategories are useful, a broader term is needed that can encompass all these varieties and additionally extend to the type of traumatic war and postmemory life writing that also entails recipes as I discuss in this article. Because gastrography is both too medical sounding and is indeed already used in medicine to denote stomach radiography, I propose the more transparent term alimentary life writing, in which 'alimentary' refers not only concretely to food but also to the action of nourishing someone and hence to human relationships. In some of my previous work I have studied a broader range of such texts, but here I limit my examples to the writings of Holocaust survivors who are Hungarian Jewish in origin and their descendants (Vasvári 2015, 2016c). Studying alimentary writing as one more category of life writing becomes particularly important today to help us understand the traumas of the Holocaust and its multigenerational traces because we are fast approaching a biological and cultural caesura, at which time direct survivors will disappear and new forms of transmission will be needed to reshape Holocaust memories for the future.

Before directly addressing the special category of alimentary life writing, we first need to consider this form of writing briefly within the context of the history and the great significance food possesses as a cultural category. Particularly emphasized in sociology, folklore, and anthropology, within these disciplines food is studied as a powerful social language that speaks of cultural traditions and inherited race, class and ethnic identity as they are constructed and passed down to following generations. As early as 1910 Georg Simmel, one of the first German sociologists, presented his "gastronomic sociology" that underscored the economic, social, religious, political and cultural importance of food. It was, however, primarily anthropologists who first recognized the importance of food in culture, most notably Claude Lévi-Strauss, who sought to explore the history of national, ethnic and religious dietary customs as part of the history of everyday life. Based on the premise that cooking is a language that - like any other language - has an unconscious structure, Lévi-Strauss argued that the roots of storytelling, art and religion are linked to cooking. See also the psycho-sociological approaches of Roland Barthes to food preferences and his categorization of food as a system of communication, although he did not go as far as to explore the communicative function of food when it is on the pages of written texts (for a more detailed background on the history and theory of foodways, see further Vasvari 2016c).

It seems that it is the elemental power of food to stimulate our olfactory system and in turn the limbic system of the human brain, where memories are stored and emotions regulated, that accounts for the popularity of food talk and food writing. In his Á la recherche du temps 
Vasvári, Louise O. "Identity and Intergenerational Remembrance Through Traumatic Culinary Nostalgia: Three Generations of Hungarians of Jewish Origin." Hungarian Cultural Studies. e-Journal of the American Hungarian Educators Association, Volume 11 (2018) DOI: 10.5195/ahea.2018.322

perdu ['The Remembrance of Things Past'], Marcel Proust wrote famously that through the image of the madeleine - which for him represented the affective memory of the senses, different from conventional memory - he was transported back in time and long-forgotten memories of childhood came flooding back: "When nothing else subsists from the past, after the people are dead, after the things are broken and scattered, the smell and taste of things remain poised a long time, like souls bearing resiliently, on tiny almost impalpable drops of their essence, the immense edifice of memory" (Proust 1981:I.24).

In biology, the humanities and cognitive psychology, such odor- and taste-evoked autobiographical memories have come to be known as the Proust phenomenon or Proustian memory; recent experiments have confirmed that such memories tend to be stronger, more emotional, and more effective reminders of past experiences originating from earlier in life than memory cues from other senses (Chu and Downes 2000, Waxman 2008: 363, Ericson 2000, Larsson et al. 2013). Scent-cued food memories can also form an important component of deep memory and of nostalgic memory, as well as bearing a connection to post-traumatic stress disorder, as shall be explored in the works I discuss below.

A major cultural function of food and eating is to link the individual to the social sphere, first through the mother and the family and then in relation to the larger social group. Foodways also serve to validate a group's social, ethnic and religious relations and self-definition while simultaneously demarcating groups by means of their food preferences and taboos. Food is also modified by gender roles, not only in differences about who cultivates, obtains and prepares food but also in relation to gendered food taboos and ritual. In many cultures women cook and serve food to men, but can only eat after the men have finished; foods prepared by women at religious and ritual ceremonies often articulate a society's deepest held values. Making, eating and talking about food also create an inevitable interface with gender-powered relationships: meals bear a particular resonance in the lives and larger domestic role of women in mothering, nurturing, and intersecting with their economic and class situation and therefore influence how their womanhood and femininity is viewed by themselves as well as by others (Counihan, Locher et al., Floyd and Forster). Particularly for women in traditional cultures, where they have so little power in public society, activities connected to food and other gendered household tasks can be the sole source of self-affirmation, ethnic identity, as well a way of maintaining cultural and familial memory (see, for example, Goeller, on Italian-American women but equally applicable to others; Jochnowitz on the cooking culture of Grushenka Abramova, a Yiddish-speaking child survivor of Romanian and German ghettos, living in the USA).

Associations attached to food, recipes, and recipe books are not only crucial to gendered family networks, but also to women's gendered identity. Prepared primarily by women, the social and physiological dimensions of food include its function as "comfort" or nostalgic food, which is associated with relief from distress, as we shall see in more detailed examples in the second part of this paper. Discussing the preparation of nostalgic food can thereby serve as a central component of nostalgic discourse. With its roots in oral storytelling, recipe sharing is a vehicle for women to exchange stories and reaffirm their identity within the community by recounting personal histories centered in food talk. Lynne Ireland introduced the concept that cookbooks are not only cultural documents, but can also be understood as a kind of collective autobiography, in which, as Ann Romines (1992: 17) explains, the "home plot" of domestic ritual and domestic language often seems invisible to those who have not learned to read it. 
Vasvári, Louise O. "Identity and Intergenerational Remembrance Through Traumatic Culinary Nostalgia: Three Generations of Hungarians of Jewish Origin." Hungarian Cultural Studies. e-Journal of the American Hungarian Educators Association, Volume 11 (2018) DOI: 10.5195/ahea.2018.322

Particularly for women without access to other forms of creative expression, cooking can become a traditional means for displaying their talents and indirectly attain influence in their household and community.

Even when published under a single name, recipe collections and cookbooks are often examples of women's social exchanges and of collective writing, as is demonstrated by, for example, the community fundraising cookbooks ubiquitously found in the United States, most especially The Settlement Cookbook. Compiled by Lizzie Black Kander (1858-1940), a Milwaukee native of German-Jewish background. The Settlement Cookbook was first published in 1901 to help East European Jewish immigrant women learn housekeeping skills in the new country. Over the next century, this volume became the best-selling cookbook of all time, with over two million copies (Koenig, Theophano) sold. Acknowledging the important role such cookbooks played in Jewish women's culture, Barbara Kirshenblatt-Gimblett studied Jewish community cookbooks as unique cultural artifacts applicable to the study of Jewish womanhood and family culinary tradition. While feminist scholars have re-evaluated recipes and recipe collections as a form of episodic and anecdotal, non-chronological and often communal gendered life writing, they have also studied how domestic ritual has helped to shape some of women's more strictly literary writing and life writing. In women's writing, food preparation appears as a helpful prop for the protagonist as the comfort of the routine concentration kitchen tasks demand enables her to cope with grief and loss of hope (on which, not merely in the context of the Holocaust but much more broadly, see further Vasvári 2015).

\section{Alimentary Life Writing as Trauma Literature of War and the Holocaust}

In Nazi Germany, the Jüdischer Frauenbund (JFB) ['League of Jewish Women'] was the first German women's organization founded in Weimar Germany. Specifically targeting Jewish women as part of a moderate, middle-class feminist movement, JFB aimed to strengthen Jewish women in their faith and enhance the values of housekeeping, a goal it attempted to reach by publishing the Kochbuch für die jüdische Küche ['Cookbook for Jewish Cooking'] (Düsseldorf, 1926). Until its dissolution by Hitler in 1938, JFB also encouraged women to produce cookbooks as a way of trying to maintain a normal, hopeful life (Kaplan). Later, during World War II andin spite of the starvation in camps, or perhaps precisely because of it-prisoners took personal risks in order to produce a previously unrecognized but, as it turns out, rather prolific subgenre of war literature that includes individual and collective recipe writing and needs to be considered within the broader context of prison literature (Godderis). Although it is now slowly beginning to become evident that a significant number of recipe collections have emerged as a result of wars, it is primarily a few female Holocaust historians who have considered the significance of war food-writing as a survival strategy (Goldenberg, Saidel). In contrast, some male scholars, representing a tendency in American Holocaust studies of perceiving the widespread commodification and sacralization of the Holocaust, have criticized this genre as kitsch. For example, Andrew Furman (1999: 95) refers to In Memory's Kitchen (Da Silva 1996), the first well-known published Holocaust cookbook, whose tragic history is discussed in more detail below, as a "pseudo-cookbook that collects grossly inaccurate ingredients, amounts, glaring misspellings and crucial omissions... whose publication posthumously humiliates these women who painstakingly labored when starvation had robbed them of every clear thought." Similarly, Tim Cole in his Selling of the Holocaust (1999: 15, n. 60; 16) also categorizes In Memory's 
Vasvári, Louise O. "Identity and Intergenerational Remembrance Through Traumatic Culinary Nostalgia: Three Generations of Hungarians of Jewish Origin." Hungarian Cultural Studies. e-Journal of the American Hungarian Educators Association, Volume 11 (2018) DOI: 10.5195/ahea.2018.322

Kitchen as Holocaust exploitation, comparable to "trashy" literature, toys, and death camp tourism. Although elsewhere Cole has written eloquently about starvation in the camps, he did not seem to understand either how such cookbooks related precisely to starvation in the camps or the motivation of the women who shared their recipes as a way of spiritually dealing with starvation and their dehumanization. While many examples of alimentary writing have their origin in women's struggle to resolve personal and familial traumas ranging from mourning the loss of a mother to parental abandonment, infidelity, divorce, migration and displacement, or the attempt to create new personal and communal identities in immigrant life, the kind of alimentary life writing created during wartime (such as in prisoner-of-war or concentration camps) is no longer an individual activity nor merely a form of nostalgia, but rather a crucial and constant component of the everyday world of the camps. It was, however, primarily women who exchanged recipes; when they could lay their hands on scraps of paper and needle and thread, or get these items in exchange for bread, many women wrote down recipes on scraps of paper. Some even managed to create manuscript cookbooks, although we will never know how many because often both the writer and the papers vanished. However, even today such collections surface from private archives at the death of a survivor. An unknown number languish uncatalogued in Holocaust libraries.

Food talk and food writing helped to constitute the Alltag ['everyday'] of prisoner culture of concentration camps and can be compared to the role filled by music and camp humor in providing a coping mechanism that served to build cohesion while also delivering criticism. In the midst of starvation, prisoners of both sexes sometimes combined food talk with humor by making jokes about starvation. Sent from Auschwitz-Birkenau to the Sömmerda munitions factory in Germany as slave laborers, a group of six young Hungarian women managed some access to paper scraps and pencil and organized a camp newspaper, the Szürkeújság ['The Gray Newspaper'], in which they used tragicomic black humor to report on "fashion," food, and other aspects of camp life (Németh-Ványi; the manuscript is located in the Holokauszt Emlékközpont ['Holocaust Memorial Center'], Budapest; see also http://www.hetek.hu/hatter/201504/a_szurke_ujsag_rovataibool). In a column called Konyhamúvészet ['The Cooking Arts'] one of the columnists wrote that:

In contrast to earlier now the only art is if we are able to cook anything in the block. Our scared häftling comrade who was able to take possession of two potatoes during potato control, hid them in place of her emaciated breasts and so managed to avoid detection [This and all subsequent translations are mine].

Az eddigektöl eltérően most kizárólag az müvészet, ha a blockban megfözünk valamit. Megszeppent häftling társunk aki pont krumpli kontroll idején tett szert 2 krumplira, lefogyott mellének helyére tette, s igy megmenekült bajtól.

The fact that food talk was part of the broader intimacy of sharing details regarding the personal lives of women in the camps is detailed by Giselle Perl (1907-1988), the head inmate gynecologist in Bergen-Belsen. In her immediate postwar (1947) volume, I Was a Doctor in Auschwitz, Perl describes how, after having run away, dazed, one evening from a Polish prisoner who had offered her the shoelaces she desperately needed for her oversized men's shoes in 
Vasvári, Louise O. "Identity and Intergenerational Remembrance Through Traumatic Culinary Nostalgia: Three Generations of Hungarians of Jewish Origin." Hungarian Cultural Studies. e-Journal of the American Hungarian Educators Association, Volume 11 (2018) DOI: 10.5195/ahea.2018.322

exchange for sex in the latrines, she devised a plan to get her fellow women inmates to talk about their past lives as a way to maintain her human dignity:

The same evening, after retiring to our bunks, I began to put my plan into effect. Instead of going to sleep as usual, I began talking in a low voice to the women lying close to me. I told them about my old life in Máramaros Sziget, about my work, my husband, my son, the things we used to do, the books we used to read, the music we used to listen to.... To my surprise they listened with rapt attention, which proved that their souls, their minds were just as hungry for conversation, for companionship, for self-expression as mine. One after the other, they opened up their hearts, and from then on half our nights were spent in conversation. Later, as we came to know one another better, we invented games to keep our minds off the sordid present. We recited poetry, told stories of the books we had read and liked, and sang songs, in a low voice, with tears in our eyes, careful that the Blockova shouldn't hear us (Perl 1947: 9).

Whether written shortly after Liberation or decades later, many such conversations abound in women's camp memoirs. Not surprisingly, these works frequently include recipe talk as an important feature of their wartime experiences. Deported from Kaposvár to Auschwitz at the age nineteen, Judith Magyar Isaacson (1925-2015) wrote in Seeds of Sarah: Memoirs of a Survivor (1990: 77) that right from the very beginning "everybody talked of home now-mostly of recipes and men" in the camp. Livia Bitton-Jackson, deported at age thirteen from Somorja (now Samorín, Czechoslovakia), describes in Elli: Coming of Age in the Holocaust how women working twelve hours a day to level a hilltop for construction mostly talked about the food they cooked at home. She recounts that the recipes discussed recalled the taste of Shabbat meals and followed the calendar of Jewish holidays:

For Shavuot, for instance, there was a conversation about flaky Hungarian strudel [....] when our appetite for rich stuff slackened, we talked of the simple food; soups, meat, bread with butter, and the Hungarian yellow paprika mother used to prepare for our school lunches. These memories of simple meals sometimes fulfilled and satisfied us emotionally more than the elaborate cakes and heavy food (Bitton-Jackson 1980: 87).

From a poor, provincial Orthodox family, it is only natural that Bitton-Jackson recalled these kinds of holiday meals; as is illustrated below, many other more urban and assimilated women talked of a broader range of not necessarily Kosher or even Jewish-style recipes.

In Egy újságírónö magányjegyzetei ['The Private Notes of a Woman Journalist'] (1986), Olga Ábel (1905-1987), from Kolozsvár (Cluj), a generation older than the younger women, some of whom had no actual cooking experience, writes in more detail about recipe talk. Ábel explains that women not only vied with each other in their recipe creations and in boasting about how they had catered to their husband's culinary whims, but that they also planned menus for when they would be liberated, intending to cook sweets like palacsinta ['crèpes'] or túrós gombóc ['farmer cheese dumplings'] and even imagining a postwar emigration to a foreign land where they would open a Hungarian restaurant: 
Vasvári, Louise O. "Identity and Intergenerational Remembrance Through Traumatic Culinary Nostalgia: Three Generations of Hungarians of Jewish Origin." Hungarian Cultural Studies. e-Journal of the American Hungarian Educators Association, Volume 11 (2018) DOI: 10.5195/ahea.2018.322

We only got turnip soup, but our fantasy started working. The women competed with each other to 'invent' for themselves and for their bunkmates the most extraordinary dishes. 'You know, I only cook with olive oil,' said one woman with such naturalness as if she had just taken a carefully stirred vegetable stew off the stove. "Well, my husband wouldn't eat anything if it was prepared with oil and I even make vegetable stew with béchamel." After the recipes came the plans about who will cook what when they get out of the hell of the lager. Some decided that they would not get up from the table until they had devoured twenty palacsinta, while others were preparing their stomach for túrós gombóc. But the more moderate ones were satisfied with a good bowlful of caraway soup. Heaven knows who started it, where it all began, but they started in on taking notes on each other's recipes. And some of them didn't do it just for the pleasure: 'If I end up in Palestine, Spain, or Turkey, I'll open a Hungarian restaurant.'

Maradt tehát a répaleves. Ám müködni kezdett a fantázia. A nök egymással versengve "találták fel" maguknak es priccsszomszédjuknak jobbnál jobb fogásokat. "Tudod, én csak olívaolajat használok" - mondta egyikük olyan termszétes egyszerüséggel, mintha most vette volna le a tüzhelyröl a gondosan elkavart fözeléket. "Az én férjem még a fött ételt sem enné meg, ha olajjal készül, fözelekékre is besamelt teszek.” A receptek után következtek a tervek, ki mit fog legelöször fözni, ha kiszabadul a lágerpokolbol. Volt, aki elhatározta, fel nem áll az asztaltol, amig husz palacsintát be nem kebelez, volt, aki túrós gombocra készitette elö gyomrát. De a szerényebbje beérte egy jó tányér izletes köménymaglevessel. Hogy ki kezdte, honnan indult el, jó ég tudja de a nök hozzáfogtak az egymástol tanult receptek feljegyzéséhez. Némelyek nem csupán kedvelésböl: "Ha elkerülök Palesztinába, Spanyolországba vagy Törökországba, magyar vendéglöt nyitok" (Ábel 1986:164).

Lillian Berliner (Kolozsvár/Cluj 1928- ), who survived Auschwitz together with her mother and later came to the United States in 1947 as a war bride, described concentration camp recipe talk in her memoir And the Month Was May in similar terms to Ábel:

We were starved in Austria and to alleviate our numerous hunger pangs, we invented frequent "dream meals" ranging between coffee klatches luncheons informal and formal dinner parties. We planned our menus carefully for hours and in great detail. Our favorite dishes and desserts took priority and were frequently repeated. The table settings, the color of dishes, tablecloths, napkins, flowers for each occasion and the seating arrangements were also discussed.... This may sound delusional I know, but during these meal planning sessions we were briefly transported to a normal world, a world that was so far from our miserable reality. We actually tasted the dishes we prepared and our hunger pangs disappeared during the hours of planning. We could hardly wait for the next planning session (Berliner 2009: 18).

Another interesting testimony, one of the minority that contains a very negative opinion of camp recipe collecting, came to light only recently. Written between Christmas 1944 and January 1945 by Lili (Radvány) Szondi (1902-1986), wife of the renowned Hungarian psychiatrist, Leopold Szondi, relayed her experiences in a refugee camp where she had recently 
Vasvári, Louise O. "Identity and Intergenerational Remembrance Through Traumatic Culinary Nostalgia: Three Generations of Hungarians of Jewish Origin." Hungarian Cultural Studies. e-Journal of the American Hungarian Educators Association, Volume 11 (2018) DOI: 10.5195/ahea.2018.322

arrived from Bergen-Belsen, together with her family and over 1,600 others on the notorious Kásztner train, the result of a ransom agreement a group of Americans had made with Eichmann. Although this group lived under very difficult conditions in the camp and received very limited rations, their situation cannot be compared to that of regular inmates, as they remained there temporarily and in a totally separate area where they were housed in family groups, retained all their own belongings and received more rations. Once Szondi had safely arrived in Switzerland, she wrote in a letter to Magda Kerényi, wife of the philosopher Karl Kerényi, about her and her family's near starvation in Bergen-Belsen, yet still considered the exchange and writing of recipes she observed there among other women in her group as pathological:

I never had occasion to enjoy so many culinary pleasures as in Bergen-Belsen.

I was absolutely clear then about the fact, and now I see it confirmed, that never again would anything taste as good to me as did a thin slice of bread and butter there.

Mrs. Farkas and her daughter, Mrs. Widrich, sit down with fervor to copy recipes, but they won't even look at a recipe that contains fewer than ten eggs. In fact, the writing of recipes appeared almost as a psychic illness in the camp. Everyone is copying recipes. People copy them in the belief that as soon as they again live normal lives they will cook and bake all day, but I know that it is in this form that they satisfy their housewifely needs, and besides, they want to try and imagine, for example, a Russian cream torte at least in writing.

Soha annyi kulinaris örömben nem volt részem, mint Bergen-Belsenben. Teljessen tisztában voltam vele és most beigazolva látom, hogy soha nem fog ugy nekem semmi izleni, mint ott egy vékony szelet vajas kenyér.

Farkasné es lánya Widrichné, szenvedéllyel nekiülnek receptek másolásának, de 10 tojason alul receptre rá sem néznek. A receptirás különben majdnem, mint lelkibetegség lépett fel a táborban. Mindenki recepteket másol. Az illetök abban a hitben irják, hogy amint normális életet fognak élni, ugy is egész nap sütni és fözni fognak, én azonban tudom, hogy ebben a formában élik ki háziasszonyi szükségleteiket, azonkivül legalább irásban kostolgatják és próbáják elképzelni például az oroszkrém tortát.

(Kovács, Szondi-Radványi: Szombat 06-06-2017 http://www.szombat.org/tortenelem/szondi-radvanyi-lili-egy-nap-bergenben)

Elisabeth M. Raab, originally Raab Böske (1921- ), who lost her parents and infant daughter in Auschwitz, both wrote down recipes in a work camp and also wrote the memoir, And Peace Never Came (1997). She describes in detail how her own obsessive recipe writing served a psychic need that made her feel ashamed:

It might have started on an especially hungry day, this recalling of recipes.

'Chocolate, eggs, the nuts and butter.' 'Stir till fluffy...fold in carefully.'

Around us everything was grey. The factory, the machines, the sky, the 
Vasvári, Louise O. "Identity and Intergenerational Remembrance Through Traumatic Culinary Nostalgia: Three Generations of Hungarians of Jewish Origin." Hungarian Cultural Studies. e-Journal of the American Hungarian Educators Association, Volume 11 (2018) DOI: 10.5195/ahea.2018.322

women, their faces, their tattered rags; all was grey, hopelessly grey, and we were starving.

'... for holidays. I used to make it, this chocolate-cream-filled

torte, I decorated it with candied nuts....'

I listened ashamed of the fool in me who even felt like listening to circumstances which had never existed or, if they had, no longer counted. I was ashamed to let myself be drawn in. I was ashamed of present reality. As if unaware of the question, 'What's the use?'

But a strong distant picture demanded voiced: the loving labor of preparing it, and the devotion, art and beauty in its creation, the pride, the respect of those faces around the festive table who knew a torte's deeper meaning.

I jotted down all that I could

I jotted it down on scraps of paper found in trash cans in the Factory-taken, stolen. They were pieces covered in penciled recordings of German workers' wages, but I overlooked the words underneath. I wrote the ingredients down, hardly able to grip the stump of a pencil, the recipes of nameless women-whoever happened to pass by. I kept on writing down the ingredients, words enshrouded in secret meaning and language in my mind.... Unnoticed was the delicate idea of my friend Eszter, who collected my scraps of paper and bound them into a recipe book, which she returned to me as a gift (Raab 1997: 81-82).

Raab recounts how her camp sister, Eszter, who helped her survive, bound a recipe book for her with a cover made of oil-soaked rags she had found in the garbage (a photo of the book volume appears on page 80 of her memoir). Although Raab lost touch with her friend in the postwar chaos of 1946, she still had the book fifty-three years later and used it to reproduce the recipe for walnut torte with chestnut cream. Note also in Raab's passage her eloquent description of how everything was grey in the camp, which explains why the six girls in Sömmerda camp discussed previously also called their camp newspaper, Szürke újság. Here is Raab's very imprecise recipe, in connection with which she explains that Hungarian recipes did not need to direct every step because the culture assumed that cooks would know what to do:

\section{Walnut Torte}

6 yolks, 171/2 sugar, 14 ground walnuts, 10 chocolate softened, 6 beaten egg whites Cream: 10 chocolate, 10 sugar, 1 dcl water, all mixed and warmed. Add 3 yolks, one by one, when cooled to lukewarm, then beat in 15 butter.

\section{Chestnut Cream}

I kg chestnuts cooked in milk. Add rum, butter, sugar, chocolate to taste. (Raab 1997: 83).

A particularly interesting recipe archive housed today in Yad Vashem combines a detailed Hungarian menu with the kind of black humor displayed in the Szürke ujság joke about stealing potatoes. This document is part of the testimony of Jehudit (Aufrichtig) Taube (Hungary 1914- Israel 2003), who immigrated to Amsterdam in 1938 from Hungary as a nanny to a Jewish family. There she joined the Resistance, but was betrayed by a Dutch woman and deported to Westerbork and Ravensbrück, the only major woman's concentration camp. Here, 
Vasvári, Louise O. "Identity and Intergenerational Remembrance Through Traumatic Culinary Nostalgia: Three Generations of Hungarians of Jewish Origin." Hungarian Cultural Studies. e-Journal of the American Hungarian Educators Association, Volume 11 (2018) DOI: 10.5195/ahea.2018.322

she was put to work in a Siemens factory where she and her friends wrote fantasy recipes and created recipe books, which she describes in the following:

We had low quality white paper. We took out a large sheet and folded it into small pieces. I bought a thread and needle and sewed it that it would not come apart, and we wrote in it. I will never forget how a Dutch woman told me: 'I have pear kugel, write it down.' I replied: 'I've never eaten it, so I don't crave it.' She insisted: 'But it would give me such pleasure to talk about it.' So, I did her a favor and jotted it down (https://www.yadvashem.org/education/educationalmaterials/artifacts/yeudit-taube.html).

At the same Yad Vashem site where the above passage is located, an amazing little note handwritten to Taube in Hungarian can be found as both a Hungarian facsimile and in an English translation. This note was composed by her best friend in the camp, Edith Gombus, who gave it to her with a small piece of bread when Yehudit was ill and missed the daily food distribution. Edith provides a very detailed menu for the imaginary five meals she and another friend, Klári, consumed in the course of the day, the kind of Austro-Hungarian menu similar to the ones in prewar Prague described by Joseph Wechsberg (1954: 14), where it was customary to have breakfast, a ten o'clock dejeuner à la fourchette, lunch, afternoon jause, and supper. The menu described here is not "fantasy-cooked," as in the foregoing examples, but only "fantasy-eaten," with Klári reporting that they had gorged themselves and all they saved for Jehudit was the small piece of bread Klári was bringing her with the detailed written menu. Among the dishes Edith listed in her fantasy menu were: lángos ['deep-fried bread dough'] with fresh butter, tejfeles krumplifözelék ['potato stew with sour cream'] spárga vajban ['asparagus in butter'] and vese velövel és sült krumplival ['kidney and brain with fried potatoes']. They also "had" a number of desserts to accompany these dishes at lunch, teatime and dinner, including sült alma, vanilliás mártásban ['baked apple in vanilla sauce'], csokoladé tejszinhabbal ['hot chocolate with whipped cream'], mandulás tejeskalács ['sweet yeast bread with almonds'] and a rolled sweet bun filled with walnuts and raisins called darázsfészek ['hornet's nest']. They finally finished off their day of imaginary feasting with aprósütemény ['assorted small pastries'].

The first printed Holocaust cookbook was published in 1986 by Bosnian-Hungarian Jew Edith Peer (Zagreb, Austria-Hungary, 1914- ?), who emigrated to Australia after surviving Auschwitz and Ravensbrück. Because Peer knew German she was able to get an "office job" in Ravensbrück that gave her the opportunity to steal paper and a pencil. In tiny, dense writing, she put together a fifty-six-page-long collection written in Hungarian which contained recipes by both Jewish and gentile fellow prisoners from various countries. The recipes mostly featured desserts and traditional comfort food, such as cheese dumplings, marrow dumplings, chocolate marquise, mushroom filled with chicken liver, and töltött palacsinta ['stuffed crèpes']. Today, the original manuscript copy is in the Sydney Holocaust Museum, while most of the five hundred copies of the printed version, entitled Ravensbrück 1945, Fantasy Cooking Beyond Barbed Wire, have been discarded; Peer had planned to donate copies to Holocaust museums, but her offer was rejected because many of the recipes were not Kosher (Gilletz 2003; US Hol Memorial Museum VHA Interview Code 12595).

More than a decade older than Edit Peer, Eva (Hesse) Os[t]walt (1902-2010)—who lived to be 107 years old - was also a prisoner in the women's concentration camp of 
Vasvári, Louise O. "Identity and Intergenerational Remembrance Through Traumatic Culinary Nostalgia: Three Generations of Hungarians of Jewish Origin." Hungarian Cultural Studies. e-Journal of the American Hungarian Educators Association, Volume 11 (2018) DOI: 10.5195/ahea.2018.322

Ravensbrück and collected recipes from women of different nationalities, similar to Peer's recipe book. Although she was German, I include Eva Ostwalt here because her recipes were almost identical to those of the more secular Hungarian-Jewish women. Except for a few pages reproduced in an interview-biography written about her life by Dagmar Schroeder-Hildebrand, her detailed recipe collection has not been published. (The fact, however, deserves mention that Ostwalt - ninety-seven years old at the time - prepared several of the recipes in her collection for her interviewer!) The recipes are not particularly Jewish and even include instructions for dishes like Blutwurst ['blood sausage'], in which it is explained that fresh pork blood obtained from a hog butchering should be combined with bacon. Like most such recipe books, Ostwalt's is full of desserts, many of which she admits she had never even heard of when she wrote them down. It also includes Vanillekipfel ['vanilla crescents'] a pastry that was not only commonly prepared at Christmas, but also perhaps one of the most ubiquitous recipes in both German- and Hungarianlanguage collections. Most importantly, Ostwalt not only provided wonderful details about her recipes, but also recorded whom among her fellow prisoners had passed on which one. When Ostwalt mentions Scheiterhaufen (in Hungarian Máglyarakás) 'bonfire' as one of the desserts, her interviewer, Shroeder-Hildebrand, is shocked that a dish bearing such a name would have been talked about in a concentration camp, so Eva Ostwalt describes the recipe as a kind of baked bread pudding with apples, raisins, and a filling of nuts or sweetened pot cheese.

Still another example of recipes remaining in forgotten family archives are the recipes of Mrs. István Endrei, Hedvig Weiss (1914-2012), Szakácskönyv a túlélélésről ['A Cookbook About Survival'] (2014), edited by Szilvia Czingel, a folklorist and musicologist who participated in collecting oral history from survivors for Centropa, an organization that investigates Central and Eastern European Jewish life from the turn of the previous century to today (http://www.centropa.org/hu). When Czingel was interviewing her in 2007, Weiss wanted to show her a recipe for flódni ['an apple, walnut, and poppy seed layered pastry'] as an example of the kinds of recipes she used to prepare with her mother. As Weiss opened a cookbook on her bookshelf, the sheets of her miniature, wartime cookbook fell out. The oral history part of the volume, in which Weiss recounts her youth in Budapest near the Nagycsarnok ['the Great Market Hall'], provides an eloquent picture of lower-middle class life in Budapest between the two world wars. In the later part of her story discussing her wartime experience, Weiss recounts that she lived with her husband for only a few weeks, as he subsequently disappeared in munkaszolgálat ['Jewish Labor Service']. When she herself had to report on November 9, 1944 to the téglagyár ['brick factory'] in Buda, the collection point for deportation, deportees were sent home to come back the next day because no transport was available, but the concierge of her building went to the police to denounce her as having escaped. She and four other starving Jewish women arrived in December 1944 in Lichtenwörth, near Wiener Neustadt, to a lager that housed 2,500 Hungarian women (Lappin-Eppel 2010: 372-374). Weiss explains how the women would recount family stories and share recipes. While Lichtenwörth was not a death camp per se, starvation was constant and the inmates were often deprived of food for two and three days at a time; like in other camps, when they did get something to eat it was constantly soup of potato skins or marharépa ['cattle turnip/ a kind of turnip used for animal fodder'].

While dictating recipes the women would also tell family stories, and Hedvig became the scribe for the cookbook because she had a pencil and paper and, as she recounts in the oral history, she wrote in very small letters in a tight script: "I just kept on writing with very small 
Vasvári, Louise O. "Identity and Intergenerational Remembrance Through Traumatic Culinary Nostalgia: Three Generations of Hungarians of Jewish Origin." Hungarian Cultural Studies. e-Journal of the American Hungarian Educators Association, Volume 11 (2018) DOI: 10.5195/ahea.2018.322

letters, so that it would fit on the paper. We had no special consideration for what kind of recipes we wrote down, just what happened to occur to us" [Én csak írtam, nagyon apró betükkel, hogy elég legyen a papír. Nem volt szempont, hogy milyen típusu ételeket írunk. Ami éppen eszünkbe jutott (http://www.centropa.org/biography/hedvig-endrei-0). Weiss recorded one hundred-fortynine recipes in total; contrary to what she thought, there was indeed a particular consideration as to which recipes were dictated by the starving women, even if they were not aware of it at the time. Among the nearly one hundred-fifty recipes in the collection, all kinds of foods are recorded but especially nutritionally rich ones and desserts. The recipes all represent CentralEast European gastro-culture, and therefore contain a lot of sour cream, for example. It is noticeable that no soup or fözelék ['vegetable stew'] is featured among the recipes; an abundance of desserts, fatty foods and meat and potatoes are found instead. Although there are some Jewish dishes, such as tüdös hurka ['lung sausage'], there is also nothing Kosher about the recipes. It was only after Weiss's death that the Szakácskönyv was published by Czingel, who reported that others have brought her similar recipes since the book was published. The book has been adapted as a play performed in restaurants, during which the audience is also served food from recipes in the book.

Two brief memoirs by camp survivors Zsuzsanna Fischer Spiro (1925- ), from the small village of Tornyospalca, located in the Northeast Great Plains of Hungary, and Eva Shainbaum (1930-), from a village near Nagyvárad (Oradea), Transylvania, published together in one volume as late as 2016, are illustrative of how food nostalgia can serve as part of the evocation of an imagined prewar "Golden Age" while simultaneously serving as a marker of social class and religious identity. Both women recall happy prewar family lives and a provincial culture that was later erased. Although both were from Orthodox families and they devote special attention to the description of Jewish holidays, in their recollections it is holiday meals that serve as a means of transmitting Jewish customs and heritage, rather than any mention of specific religious observance. Spiro mentions that among the holiday foods that she particularly liked as a child was an unnamed dish that she describes as chicken that tasted like fish, which I did not understand on first reading. I learned that when fresh carp was either not available or unaffordable, poor Jews would make an imitation Sabbath gefilte fis out of poached ground chicken. While this clearly could not have tasted like fish, it was prepared and looked the same way as if it had been. In Yiddish this dish was called faltsche fis ['false fish'] or bailik fis ['cheap fish']. For very devout Hasidic Jews, yet another reason for preparing this dish was that they did not eat fish on Passover because they feared the fish might have eaten a piece of bread and had not completely digested it by the time it was caught (Altman 2009), so they replaced the ritual fish dish with its closest imitation. In the memoir Spiro originally recorded for her family in 1976, she also delineates how, in October 1944, she and her sister were sent on a slave labor transport from Auschwitz to Markkleeberg, found near Leizig, to a Junkers aircraft factory where they were part of 1,300 Hungarian women slave laborers. She recounts that when the women were not working, one of their favorite topics was to exchange recipes. She surmised that they thought it would help them forget how hungry they were, but that it was an activity she herself did not engage in and did not even like to listen to (Vasvári 2016a). 
Vasvári, Louise O. "Identity and Intergenerational Remembrance Through Traumatic Culinary Nostalgia: Three Generations of Hungarians of Jewish Origin." Hungarian Cultural Studies. e-Journal of the American Hungarian Educators Association, Volume 11 (2018) DOI: 10.5195/ahea.2018.322

\section{Into the Next Generation: from Recipe Collection to Food Memoir}

Holocaust recipes continue to provide a foundation for life writing into the 1.5 , second and even third generation of Holocaust survivor families. Sári (Slovak) Biró (1904-1995), who received a notebook for writing up recipes for her wedding in 1925, can serve as a transition to the second group of recipe writers I will discuss more briefly, namely, the children and grandchildren of survivors who wrote culinary memoirs many years later. Biro kept adding recipes to her notebook and became a well-known cook in her prewar social circle of bourgeois Jews in Budapest. She took the notebook (which simultaneously served her as a diary) first to the ghetto, then years later to prison, where she was held for several months for trying to cross the border illegally under communist Hungary. When word about her cooking skills got out in the prison, she was asked to cook for the staff and the prisoners. In 1957 she was finally able to leave Hungary and (without her husband) joined their daughters, who had fled to the United States in 1948. There she first took care of a child, then started baking, catering and translating her recipes into American measurements. She eventually wrote Flavors of Hungary: Recipes and Memoirs (1973). With its striking cover of dancing peasant girls in traditional costume, this volume became a bestseller and was reprinted several times. The book's subtitle as well as its marketing as a "bittersweet memoir... a riches-to-rags tale" claims for itself the term "memoir" as in the brief Introduction the author does include bittersweet memories of her homeland. However, Biro assiduously avoids divulging that she is Jewish, as was not uncommon among upwardly-mobile assimilationist Hungarian Jews. She concocts for herself a fantasy autobiography of having grown up in a rich, presumably gentile family; as for the war, she says not a word about the persecution of the Jews but only claims that her family spent most of their time in a bomb shelter. She does, however, talk in some detail of her subsequent imprisonment under the communist regime.

It is only Biró's daughter and 1.5 generation survivor, Agnes Biro Rothblatt, who in her own 2010 fragmentary memoir, A Journey from the Chain Bridge to the Golden Gate, puts her mother's manuscript recipe book in context in a way that her mother could not allow herself to divulge. She touchingly writes of her mother's attachment to her recipe notebook throughout the vicissitudes of her life:

Sárika took her cookbook along [to the ghetto]. It became her diary and was her journal. The changes in lifestyle, cooking method, and family events were all in there. Memories of her mother, Mama, her life as an aspiring socialite, her attempts as a creative cook, caring mother, and, later, survivor in a war-torn city, were recorded on those pages. The book's cover was no longer shiny but worn and faded.... She covered the book with a clean newspaper and tucked it into her air raid shelter pack. Maybe it would be useful after the war is over, she thought, or her two daughters might read it when the world normalized again (Rothblatt 2010: 6).

Biró's history of her cooking ability becoming the key to her creating a new life after immigration is not an unfamiliar one for other women of her generation, such as Paula Stern Kissinger, mother of Henry Kissinger, who recounts in 1996 at the age of ninety-six that when she arrived from Germany to New York City with her husband and two young sons in 1938, she had to cook out of necessity to support her family because her husband Nathan's English was not good enough to get him a job as a high school teacher. A decade earlier than Biró, Jolie Gábor 
Vasvári, Louise O. "Identity and Intergenerational Remembrance Through Traumatic Culinary Nostalgia: Three Generations of Hungarians of Jewish Origin." Hungarian Cultural Studies. e-Journal of the American Hungarian Educators Association, Volume 11 (2018) DOI: 10.5195/ahea.2018.322

(Budapest 1896? - New York 1997), mother of the famous Gabor sisters, also published a Hungarian cookbook, Jolie Gabor's Family Cookbook (1962), a follow-up to her ghost-written autobiography in which she, like Biró, invented a new, gentile past for herself. Nevertheless, many of the recipes clearly show their Jewish Hungarian origin, such as broiling chicken livers for a stuffing recipe, preparing both stuffed cabbage and Szeged gulyás with beef rather than pork, the usage of chicken fat for cooking, as well as her recommendation to serve farmer cheese and noodles with sugar rather than with bacon.

As of the late 2000s, a crop of specifically food nostalgia, memorial-type recipe books has emerged that were compiled by the children of survivors who either collected recipes directly from survivors, or from their own memories of meals prepared by mothers or grandmothers. This process thereby links the Holocaust to culinary Jewish memories, sometimes intentionally shifting the emphasis from recipes of victims to stories of survival. One such collection, the Holocaust Survivor Cookbook: Collected from Around the World (2007), was compiled and selfpublished by Joanne Caras, daughter a Holocaust survivor. Caras's recipes are untested and she published the recipes as she received them, often incomplete and outdated, accompanied by one hundred stories by survivors and pictures of their presumably happy families before the war. Instead of being organized by courses, the dishes in the book are compiled according to recipes provided by a given survivor grouped together. One of the contributions in this memorial cookbook is by survivor Lillian Berliner, from whose memoir a passage describing Auschwitz "dream recipes" is quoted above. Here Berliner provides recipes for Liptauer spread and palacsinta, with the former adapted, as so many of the recipes in the collection, to American ingredients, in this case by substituting cream cheese for the original sheep cheese.

\author{
Liptauer spread (dairy) \\ 8 oz. whipped cream cheese \\ 4 oz margarine \\ 11/2 TB minced onion \\ 2 squirts anchovy paste (not too much, since very salty) \\ paprika - to redden the spread \\ Mix well. Refrigerate. Serve with crackers or bread. \\ (https://gourmania.com/the-holocaust-survivor-cookbook-recipes-seasoned-with-bittersweet- \\ memories/)
}

One of the more historically informed and interesting, as well as professional, works in the memorial cookbook category is Lynne Kirsche Shapiro's Food, Family and TraditionHungarian Kosher Family Recipes and Remembrance (2014). Kirsche's father was Sándor Kirsche (originally Shalom Kirschenbaum), born in Hluboka in the Carpathian region of what was then Czechoslovakia, while her mother was born in Gergely, Hungary. After surviving Auschwitz and other camps, they met in a Displaced Persons camp in Germany, married in 1947 and came to the United States in 1948, where they built up an enormously successful food import store. In the first part of Food, Family, and Tradition Kirsche Shapiro completed her father's unfinished autobiography, which had been interrupted by his death. In the second part of the book she provides one hundred-fifty Hungarian recipes that she had collected from her mother and from other relatives. Her mother had never written down any recipes but, although already blind, she was able to help her daughter translate her Hungarian recipes, which meant not merely 
Vasvári, Louise O. "Identity and Intergenerational Remembrance Through Traumatic Culinary Nostalgia: Three Generations of Hungarians of Jewish Origin." Hungarian Cultural Studies. e-Journal of the American Hungarian Educators Association, Volume 11 (2018) DOI: 10.5195/ahea.2018.322

a linguistic translation but translating a "pinch" or a "handful" into precise measurements. Kirsche Shapiro places all the recipes in the context of biographical vignettes from preHolocaust and Holocaust Hungary, which provides a historical and cultural background. She dedicates the volume as a tribute to all Holocaust survivors and to the continuity of the legacy of Jewish life before the Holocaust through food and culture. She proudly recounts that - although she herself was born in the US - she "journeyed back home" with her parents so she was able to see for herself the plum trees on the Kirschenbaum land from which her mother would make szilvalekvár ['prune plum preserves'], for which she provides the recipe. All of Kirsche Shapiro's recipes are strictly Kosher, so it is interesting, for example, that in her recipe for very traditional Hungarian rakott krumpli, a potato and egg casserole which combines sour cream and pork sausage, she replaces the meat with sautéed onions. Less appetizing to my own unreconstructed Hungarian palate, is the Americanized variation that she suggests for the dish by adding two to four ounces of shredded cheddar cheese on top before baking it. She also provides a recipe for the-hitherto unknown to me-false fish [sic] to which I was first introduced in Zsuzsanna Fischer Spiro's memoir. When asked by an interviewer what her own favorite recipe is, Kirsche Shapiro replied that it was chicken paprikás ['chicken cooked in paprika sauce'], one of her mother's signature dishes, and she places the dish within the context of one of her mother's recalled stories, thereby wonderfully typifying the deep, traumatic food nostalgia underlying much of alimentary life writing:

The setting for the story began after my mother was liberated. Making her way back to her hometown, she thought that she was the only member of her family to have survived. Then, six months after returning to her hometown, she heard that her brother, Morton, had survived and was living in Freising, Germany. She started on her way to find him and stopped in Budapest at a friend's apartment. While cooking chicken paprikás for dinner at her friend's apartment, she heard a knock at the door. Because her friend was busy, my mother went to open the door. Before her eyes stood her brother. He had heard that my mother was alive and was on his way to find her, so he had stopped at the same friend's place on his way. I get the chills each time I hear this story. To me this recipe symbolizes home and family. Even today, the aroma of this dish wraps me in the wonderful comfort of home (Richmond: http://divafoodies.com/cookbook-author-lynn-kirsche-shapiro/)

A second-generation Hungarian who lives in France, Viviane Chocas (1962- ) used food to face her struggle to retrieve her fragmented Hungarian identity that her parents, Zsuzsa and Peter (1956 Hungarian refugees to France) did not want to talk about as they would not even speak in Hungarian with her. In her 2006 culinary-themed memoir, Bazar Magyar, subtitled Les saveurs du passé sur le bout de la langue [ 'Flavors of the Past on the Tip of the Tongue'], she recounts that the only connection she had with her Hungarian origin were her regular trips with her father to the Hungarian grocery in Paris, where she would hear a bit of Hungarian, and her mother Zsuzsa's cooking. Writing about herself in the third person, she describes how she cherished the taste of Hungarian food as a substitute for a language in which, for her, the vowels were made of paprika and the consonants of galuska ['small dumplings']: "Klara cherished this connection. Her intimate alphabet is the paprika vowels and the galuska consonants, her 'grave' accents with the taste of nuts, and the sharp accents with the bitterness of cucumbers" [Klara 
Vasvári, Louise O. "Identity and Intergenerational Remembrance Through Traumatic Culinary Nostalgia: Three Generations of Hungarians of Jewish Origin." Hungarian Cultural Studies. e-Journal of the American Hungarian Educators Association, Volume 11 (2018) DOI: 10.5195/ahea.2018.322

chérit ce lien. Son alphabet intime ce sont ces voyelles paprika, ces consonnes galuska, ces accents graves au gout de noix, aigus a l'amertume du concombre] (Chocas 2006: 87).

The chapters of Bazar are all named after Hungarian foods, such as the one entitled "Les beignets d'abricots/ Farsangi fánk," in which Chocas recounts how in 1973, when she was eleven, the family first returned to Hungary for her paternal grandmother's funeral. She then lists the foods served there, including chicken soup served with the chicken feet, stuffed peppers, apple strudel and apricot dumplings. In the chapter titled "Le biscuit roulé/Beigli," she details how she learned Hungarian in secret by reading a Hungarian grammar book and reproducing from it a short text about the preparation of beigli for Christmas. In "Le chou farci/Töltött káposzta" she describes how, at the age of twenty-four, she felt a great need to visit Hungary; after describing what she ate there as well as a brief affair she had with a Hungarian whose mother cooked stuffed peppers for her, she concludes that she has the feeling of Hungarian food on her skin, in her veins, and in her pubis, bringing her to the brink of sexual climax. It took Chocas many years to find out that her family was uncommunicative because they were hiding her mother and grandmother's Jewish identity. As for Chocas's mother, only in 2005 on the sixtieth anniversary of the liberation of the camps, at age seventy, did she begin to reveal details of her past, recounting that in 1944 at the age of ten she wore the yellow star; even at this late time of life, she was only brought to make this particular confession because her brother, a professor in Paris, wrote a memoir about the family's Jewish past after his retirement.

Precisely because alimentary life writing is primarily gendered as female, it is important to add examples provided by male writers, which I shall illustrate through the three male authors, András Koerner, Mihály Dés, and Ofer Vardi. The first and oldest, András Koerner (1941- ), is a 1.5-generation Hungarian survivor living in the United States. In 2004 Koerner published a cookbook-biography, A Taste of the Past: The Daily Life and Cooking of a Nineteenth-Century Hungarian Jewish Homemaker, that was inspired by the recipes of a handwritten book of his great-grandmother, Theresa (Riza) Baruch (Berger) (1851-1938). Begun in 1869, Theresa Baruch continued to enlarge her collection almost until the end of her life. Amazingly, she was born three years after the Hungarian revolution of 1848 and died one year before the outbreak of the Second World War; although she wrote in German, she considered herself Hungarian. Koerner not only collected his great-grandmother's recipes, but also the customs, holidays and the culinary culture of his ancestor, a late nineteenth-century middle-class Jewish woman. The cookbook also reflects more broadly the social and religious life of a small Hungarian Jewish community and is a contribution to culinary history, tracing the changing food habits and other lifestyle shifts of Hungarian Jews in the latter half of the nineteenth and early part of the twentieth century, a period marked by widespread assimilation and integration. In spite of this historical backdrop, the recipes include many strictly Jewish ones, like fótt ponty ecetes lében, tormával ['pike in sour aspic, with horseradish'], cholent, and almás maceskugli ['apple-matzo kugel']. Koerner, who in 1986 moved to the United States where he worked as an architect, has become a historian of Hungarian Jewish everyday life (see the engaging blog about Koerner by the historian, Holly Case, with family photos, including that of his great-grandmother, as well as an oral history about his life with his difficult mother: www.blogspot.hu/2014/05/extendedprofile-andras- korner.html; see also Sanders 2005; see also Koerner 2015). Koerner's latest publication, his 2017 A magyar zsidó konyha - kulturtörténetek 77 autentikus recepttel ['Hungarian Jewish Cooking with Seventy-Seven Authentic Recipes'], is far more than a 
Vasvári, Louise O. "Identity and Intergenerational Remembrance Through Traumatic Culinary Nostalgia: Three Generations of Hungarians of Jewish Origin." Hungarian Cultural Studies. e-Journal of the American Hungarian Educators Association, Volume 11 (2018) DOI: 10.5195/ahea.2018.322

cookbook and is rather a cultural history discussing such issues as ritual slaughter, specific holiday meals, or famous restaurants and coffeehouses of the past, all tied together with the process of the country's Jews becoming bourgeois and striving for assimilation. Culinary issues related to assimilation include how the Hungarian chicken paprikás with sour cream deals with Kosher customs, where mixing of milk and meat is not allowed, or how sweet and sour tastes, such as in töltött káposzta ['stuffed cabbage'], were brought by immigrants from Galicia. Koerner also discusses gefilte fis, which I mentioned above in the context of chicken serving as a false gefilte fis, which as he points out, is itself an impoverished version of the Western stuffed fish, being really a halgomboc ['fish dumpling'], which also came with nineteenth-century immigrants from Galicia and the Ukraine.

A second-generation Hungarian, who spent part of his adult life in Barcelona but returned to Hungary, Mihály Dés (1950-2017) wrote 77 pesti recept. Gasztronomiai anyaregény ['77 Budapest Recipes - a Gastronomical Motherbook'], which in its first half is really a sort of family novel with some mention of the Holocaust, but primarily emphasizing life under the communist regime of János Kádár. It is also a mother portrait of his mother, a woman from a poor Jewish family who did not actually start to cook seriously until later in life, yet afterward collected recipes into her nineties. When Dés returned from living for years in Barcelona, watching his mother cook and recording the recipes was a way for him to bond with her and to save the recipes for his children, who grew up in Barcelona and for whom her cooking was a way to identify with their Hungarianness. The second half of the volume contains the seventyseven recipes, full of homey soups and vegetable stews, which in Hungary today would be called nagyi föztje ['granny's cooking'].

At the same time that the 1.5 and second-generation Holocaust children began to write alimentary life writing, so have some third-generation writers. In Israel Ofer Vardi, born in Beer Sheva in 1973, who identifies as a sabra with Hungarian cultural identity, is the grandson of four Hungarian-speaking Holocaust survivors who emigrated to Israel in 1949 and in 1957. He grew up on Hungarian food prepared by his beloved nana, the name he and his brother called his paternal grandmother, Rozsi Vár[a]di, who took care of them and fed them every day after school. In 1999 Vardi lived for a year in Hungary, where he added to his Hungarian food knowledge. After his grandmother's death in 2001, he found her battered notebook of recipes in Hungarian, which he translated into Hebrew while adding updates he received from present-day chefs in Hungary. Subsequently, in the late 2000s, he published for some time a successful weekly newspaper column called "Going Paprikash," in which he published recipes of Hungarian food culture and family stories, including those about his grandmother as representing the story of Hungarian Jewry in the twentieth century. Vardi recounts that he received many letters from readers who reacted to his column with comments like, "I almost started crying because it made me think of my grandmother." In 2009 Vardi published his Hungarian recipes in a best-selling cookbook, Goulash lagolesh-matamei hamitbakh hahungari ['Goulash for the Browser - Delicacies of the Hungarian Kitchen'], and shortly thereafter its English translation, Going Paprikash - the Best of Hungarian Jewish Cuisine (2011), in an iPhone edition including a family video with Hungarian music (Shiri 2007, Martinelli 2011). Among Rozsi's recipes that Vardi reproduces is her celebrated walnut and poppy-seed filled kifli ['crescents'], which she prepared for Purim, and the elegant and very Austro-Hungarian indianer ['cream puffs with chocolate glaze'], usually prepared only in pastry shops. Vardi also includes simple everyday recipes, such as spenótfózelék ['creamed spinach'] topped with fried eggs. Vardi's cookbook earned him the 
Vasvári, Louise O. "Identity and Intergenerational Remembrance Through Traumatic Culinary Nostalgia: Three Generations of Hungarians of Jewish Origin." Hungarian Cultural Studies. e-Journal of the American Hungarian Educators Association, Volume 11 (2018) DOI: 10.5195/ahea.2018.322

Pro Cultura Hungarica Award in 2010 from the Hungarian government. Believing that food reflects the cultural history of a nation, Vardi currently runs a cookbook and lifestyle publishing house, where he publishes cookbooks to document Israel's colorful food culture. See further Ilana Rosen on Vardi, as well as on another older male Israeli-Hungarian cookbook author, Yosef/Joseph Tommy Lapid [1931-2008], who was born in Újvidék/Novi Sad and wrote Paprika-kakha mevashum hahungarim ['Paprika - This Is How the Hungarians Cook'] (1987). Rosen raises the important question relative to culinary nostalgia of how long can diasporic generations relate to the landscape, language, colors and taste of the old country and how they keep transforming these old-country memories as their own lives in the new country keep evolving.

Another third-generation author of culinary nostalgia with a Hungarian background is Daniela Blei who, in her article, "Every Cookbook Tells a Story," makes the good point in reference to her deceased grandmother's recipes that fill a brittle-paged and butter-flecked notebook that "notebooks filled with recipes can be interesting more for the stories they tell than the flavors they promise" (16). She recounts how her newlywed grandparents, Lola and Lajos, left Prague in 1948 with her great-grandmother, Flora, the only members of their family to have survived the Holocaust. They ended up living in Buenos Aires, where her grandmother's recipe notebook begins with Argentine matambrito ['cold beef roulade'] and conforms to Argentine custom, calling for a side of Russian salad; she, however, followed such native fare with Eastern European nut tortes and fruit tarts, such as her recipe for Imperial cake calling for a dozen egg yolks and a cup of butter. But Lola's recipes as a culinary text contain another story, about migration and about immigrants using food as a way to remember the past and reaffirm who she was: Jewish, European and Argentinean, and a good cook, although not an exceptional one. As Blei concludes, her grandmother's recipes are not so much of interest for themselves, as most of them are bland and old-fashioned, but rather because they are in fact her grandmother's autobiography, delineating "who she was and where she went, from a village in the Carpathian Mountains to the Confitería Oriental" (Blei 2015: https://forward.com/food/214661/recipesfrom-my-argentine-grandmother/ ).

As Marianne Hirsch and Valerie Smith (2002: 9) have discussed in the context of traumatic cultural memory, nostalgic narratives are often dismissed as conservative or even reactionary and escapist: such retellings nevertheless can provide archives of the past. Alimentary narratives, with their access to that "deep memory" of survivors that has essentially been considered untouched, can help unlock memories. Survivors and their second- and thirdgeneration children blend their own lived experience and longing for continued group identity to bear witness to the fragmented and traumatic chapters of Holocaust history that they have exhumed, and perhaps even illuminated.

\section{Works Cited}

Ábel, Olga. 1986. Egy újságírónő magányjegyzetei ['The Private Notes of a Woman Journalist']. Budapest: Magvető Könyvkiadó.

Altman, Elissa. 2009. “A Fish Tale.” Saveur July 13 https://www.saveur.com/article/Kitchen/AFish-Tale

Bardenstein, Carol. 2002. "Transmission Interrupted: Reconfiguring Food, Memory, and Gender in Cookbook-Memoirs of Middle Eastern Exiles.” Signs 28.1: 353-387. 
Vasvári, Louise O. "Identity and Intergenerational Remembrance Through Traumatic Culinary Nostalgia: Three Generations of Hungarians of Jewish Origin." Hungarian Cultural Studies. e-Journal of the American Hungarian Educators Association, Volume 11 (2018) DOI: 10.5195/ahea.2018.322

Barthes, Roland. 1961. "Pour une psycho-sociologie de l'alimentation contemporaine." Annales Economies, Societés, Civilisations 16.5: 977-986.

Berenbaum, Michael. 2004. "Is the Memory of Holocaust Being Exploited?" Midstream April www.midstreamthf.com/200404/feature.html

Berliner, Lillian. 2009. And the Month Was May. New York: iUniverse.

Biro, Charlotte Slovak. 1973. Flavors of Hungary: Recipes and Memoirs. New York: Scribner,

Bitton-Jackson, Livia. [1984] 1999. Elli: Coming of Age in the Holocaust. London: Simon and Schuster.

Blei, Daniela. 2015. "Every Cookbook Tells a Story." Forward March 13: 16. https://forward.com/food/214661/recipes-from-my-argentine-grandmother/

Caras, Joanne, comp. 2007. The Holocaust Survivor Cookbook: Collected from Around the World. Port St. Lucia: Caras and Assoc. Inc.

Chocas, Viviane. 2006. Bazar Magyar ['Hungarian Bazaar']. Paris: Héloïse d'Ormesson.

Chu, Simon and John J. Downes. 2000. "Odour-Evoked Autobiographical Memories:

Psychological Investigations of Proustian Phenomena." Chemical Senses 25.1: 111-116.

Cole, Tim. 1999. Selling the Holocaust from Auschwitz to Schindler: How History is Bought, Packaged and Sold. New York: Routledge.

Counihan, Carole. 2012. "Gendering Food." The Oxford Handbook of Food History. Ed. Jeffrey M. Pilcher. Oxford: Oxford UP: 99-116.

Czingel, Szilvia, ed. 2013. Szakácskönyv a túlélésért-Lichtenwörth, 1944-45 ['Cookbook for Survial-Lichtenwörth, 1944-45']. Budapest: Corvinus.

Dés, Mihály. 2013. 77 pesti recept. Gasztronomiai anyaregény ['77 Budapest Recipes. A Gastronomical Motherbook.']. Budapest: Corvina.

Erickson, Robert P. 2000. "The Evolution of Neural Coding Ideas in the Chemical Senses," Physiology and Behavior 69: 3-13.

Floyd, Janet and Laurel Forster, eds. 2010. The Recipe Reader: Narratives, Contexts, Traditions. Aldershot: Ashgate.

Furman, Andrew. 1999. "Inheriting the Holocaust: Jewish-American Fiction and the Double Bind of the Second-Generation Survivor." In The Americanization of the Holocaust. Ed. Hilene Flanzbaum. Baltimore: Johns Hopkins: 88-101.

Gabor, Jolie. 1962. Jolie Gabor's Family Cookbook. New York: Thomas Y. Crowell Co.

Godderis, Rebecca. 2006. "Dining In: The Symbolic Power of Food in Prison.” Howard Journal of Criminal Justice 45.3: 255-267.

Goeller, Alison D. 2005. "The Hungry Self - The Politics of Food in Italian-American Autobiography." Prose Studies 27.3: 235-247.

Goldenberg, Myrna. 2003. "Food Talk: Gendered Responses to Hunger in the Concentration Camps." Experience and Expression: Women, the Nazis, and the Holocaust. Elizabeth Baer and Myrna Goldberg, Eds. Detroit: Wayne State UP: 161-79.

Hirsch, Marianne and Leo Spitzer. 2006. "Testimonial Objects: Memory, Gender and Transmission." Poetics Today 27.2: 353-383.

Hirsch, Marianne and Valerie Smith. 2002. "Feminism and Cultural Memory: An Introduction." Signs 28.1: 1-19 
Vasvári, Louise O. "Identity and Intergenerational Remembrance Through Traumatic Culinary Nostalgia: Three Generations of Hungarians of Jewish Origin." Hungarian Cultural Studies. e-Journal of the American Hungarian Educators Association, Volume 11 (2018) DOI: 10.5195/ahea.2018.322

Huhák, Heléna. 2014. “Női szerepek, női terhek a vészkorszakban ['Women’s Roles, Women’s Burdens in the Time of Turmoil;]." Archivnet 09.22 http://archivnet.hu/pp_hir_nyomtat.php?hir_id=495

Ingall, Marjorie. 2016. "Jewish Food and the Recipes of Our Lives." Tablet July 5, 2016 https://www.tabletmag.com/scroll/206968/jewish-food-and-the-recipes-of-ourlivelihood

Ireland, Lynne. 1981.“The Compiled Cookbook as Foodways Autobiography.” Western Folklore 40.10 (1981): 107-114.

Isaacson, Judith Magyar. 1991. Seed of Sarah: Memoirs of a Survivor. Chicago: U of Chicago P, $1991,2^{\text {nd }}$ ed.

Jochnowitz. Eva. 2011. "All You Need is a Potato: The Culinary Performances of Grushenka Abramova." Women and Performance: A Journal of Feminist Theory 21.3: 367-384

Kaplan, Marion. 1990. "Jewish Women in Nazi Germany: Daily Life, Daily Struggles 19331939." Feminist Studies 16: 579-606.

Kirshenblatt-Gimblett, Barbara. 1987. "Recipes for Creating Community: The Jewish Charity Cookbook in America." Jewish Folklore and Ethnology Review 9: 8-12.

Koenig, Leah. 2016. "As American as Pot Roast and Potato Salad." Tablet April 20 https://www.tabletmag.com/iewish-life-and-religion/199721/settlement-cook-book

Koerner, András. 2017. A magyar zsido konyha — kulturtörténetek 77 autentikus recepttel ['Hungarian Jewish Cooking — Cultural Histories with Seventy-Seven Recipes']. . 2013. Hogyan éltek? A magyar zsidok hétköznapi élete 1867-1940 ['How Did They Live? The Everyday Life of Hungarian Jews 1867-1940']. Budapest: Corvina. .2004. A Taste of the Past: The Daily Life and Cooking of a Nineteenth-Century Hungarian Jewish Homemaker. Hanover: UP of New England.

Kovács, András Bálint. 2016. "Egy kézirat sorsa ['The Fate of a Manuscript'].” Szombat 06-22 http://www.szombat.org/tortenelem/egy-kezirat-sorsa

Lappin-Eppel. 2010. Ungarisch-Jüdische Zwangsarbeiter und Zwangsarbeiterinnen in Österreich 1944/45 ['Male and Female Hungarian-Jewish Slave Laborer in Austria 1944/45']. Vienna: Lit Verlag.

Larsson, Maria et al. 2013. "The Functional Neuroanatomy of Odor Evoked Autobiographic Memories Cued by Odors and Words." Neuropsychologia 51: 123-131.

Lévi-Strauss, Claude. 1966. "The Cultural Triangle.” New Society 22: 937-940.

Martinelli, Katherine. 2011. "Tasty iPhone Cookbook: Going Paprikash,” Tablet May 26, http://forward.com/food/tag/goulash-legolash/

Németh, Vanyi Klari. 2015. "Humor a nyomoruságban ['Humor in Misery']." Hetek 19. 17, $04.24 \mathrm{http}: / / \mathrm{www} \cdot$ hetek.hu/hatter/201504/humor_a_nyomorusagban

Peer, Edith. 1986. Ravensbrück 1945: Fantasy Cooking Behind Barbed Wire. Sydney: Concord Printing.

Proust, Marcel. 1981. The Remembrance of Things Past. New York: Vintage.

Raab, Elisabeth M. 1997. And Peace Never Came. Waterloo: Wilfrid Laurier UP.

Richmond, Marianne. 2015. "Cookbook Author Lynne Kirsche Shapiro." http://divafoodies.com/cookbook-author-lynn-kirsche-shapiro/ March 3.

Romines, Ann. 1992. The Home Plot: Women, Writing, and Domestic Ritual. Boston: U of Massachusetts P. 
Vasvári, Louise O. "Identity and Intergenerational Remembrance Through Traumatic Culinary Nostalgia: Three Generations of Hungarians of Jewish Origin." Hungarian Cultural Studies. e-Journal of the American Hungarian Educators Association, Volume 11 (2018) DOI: 10.5195/ahea.2018.322

Rosen, Ilana. 2018. "Hungarian Cookbooks for Hebrew Readers - A Comparative Cultural Analysis." Manuscript.

Rothblatt, Agnes Biro.2010. A Journey from the Chain Bridge to the Golden Gate. Amherst: SmallBatch Books.

Saidel, Rochelle G. 2004. The Jewish Women of Ravensbrück Concentration Camp. Madison: U of Wisconsin P.

Sanders, Ivan. 2005. "An Artist, a Robber, a Cook." The Hungarian Quarterly 46.179: 146-152.

Shapiro, Lynne Kirsche. 2014. Food, Family and Tradition - Hungarian Kosher Family Recipes and Remembrance. Chicago: Cherry Press.

Shiri, Zsuzsa. 2007. "Magyar ízek: izraeli bombasiker ['Hungarian Flavors: Enormous Success in Israel']." hvg.hu aprilis 12 http://hvg.hu/velemeny/20070411_izrael_magyar_recept

Simmel, Georg. "Sociology of the Meal." In Georg Simmel on Culture: Selected Writings. David Frisbert, Mike Featherstone, eds. London, 1997 [1910]: 130-135.

Smith, Sidonie and Julia Watson, eds. Reading Autobiography: A Guide for Interpreting Life Narratives. Minneapolis: U of Minnesota P, $2^{\text {nd }}$ ed. 2010.

Szondi-Radvány, Lili. 2017 “Egy nap Bergenben ['A Day in Bergen'].” Szombat 06-06-2017 http://www.szombat.org/tortenelem/szondi-radvanyi-lili-egy-nap-bergenben

Vardi, Ofer. 2009. Goulash lagolesh - matamei hamitbakh hahungari ['Goulash for the Browser - Delicacies of the Hungarian Kitchen']. Tel Aviv: LunchBox[sic]. Trans. Going Paprikash - the Best of Hungarian Jewish Cuisine (2011).

Vasvári, Louise O. 2016a. "Introduction." Zsuzsanna Fischer Spiro "Fragile Moments'/Eva Shainbaum "The Last Time." Toronto: The Azrieli Foundation: 5-15. . 2016b. Nem és emlékezet a táplálkozási élettörténetirásokban a holokauszt idején és után ['Gender and Remembrance in Alimentary Life Writing During and After the Holocaust'].” Múlt és Jövö 4: 104-140 http://docplayer.hu/47301515-Magyar-nokholokauszt-eletirasai-a-megosztott-nemzeti-emlekezet-kontextusaban.html . 2015. "Introduction to and Bibliography of Alimentary Life Writing and to Recipe Writing as War Literature." CLCWeb 17.3 http://dx.doi.org/10.7771/1481-4374.2781

Waxman, Barbara Frey. 2008. "Food Memoirs: What They Are, Why They Are Popular, and Why They Belong in the Literature Classroom." College English 70.4: 363-383.

Wechsberg, Joseph. 1954. Blue Trout and Black Truffles: The Peregrinations of an Epicure. New York: Knopf. 